\author{
INTERNATIONAL BULLETIN OF BACTERIOLOGICAL \\ NOMENCLATURE AND TAXONOMY \\ Volume 9 No. 3 July 15,1959 pp. $119-122$
}

\author{
INTERNATIONAL BACTERIOLOGICAL \\ NOMENCLATURE COMMITTEE SUBCOMMITTEE \\ ON STREPTOCOCCI AND PNEUMOCOCCI
}

\title{
MINUTES OF SECOND MEETING
}

1. A meeting of the Subcommittee was held at the Karolinska Institute, Stockholm on August 2nd 1958. The following were present:

$\begin{array}{ll}\text { Dr. V. D. Allison } & \text { Belfast (Chairman) } \\ \text { Dr. B. Eddy } & \text { Washington } \\ \text { Dr. R.M. Fry } & \text { Cambridge, England } \\ \text { Professor O. Guthof } & \text { Köln, Germany } \\ \text { Dr. E. Lund } & \text { Copenhagen } \\ \text { Dr. I. Pattison } & \text { Compton, England } \\ \text { Dr. M. Plommet } & \text { Jouy-en-Josas, France } \\ \text { Professor M. Seelemann } & \text { Kiel, Germany } \\ \text { Dr. K. Skadhauge } & \text { Copenhagen } \\ \text { Dr. A. W. Stableforth } & \text { Weybridge, England } \\ \text { Dr. E. Updyke } & \text { Chamblee, U.S.A. } \\ \text { Dr. R. Wahl } & \text { Paris } \\ \text { Dr. R. E.O. Williams } & \text { London }\end{array}$

Apologies for absence were received from Dr. Rebecca Lancefield (New York) and Dr. C. MacLeod (New York).

2. Dr. Allison welcomed the members and referred to the record of the previous meeting, held in Rome in 1953 (see ISC/1).

3. Definition of "Groups" of streptococci. There was extensive discussion of the relative usefulness of serological and physiological methods of identifying groups or species of streptococci. There was general agreement that serological methods were to be preferred, but the description of a new group or species should include physiological as well as serological characterization. No new species could be described without the examination of several independent strains, isolated from different sources separated in time or space. Linguistically at least, it was undesirable to describe a new "group" unless distinct types were represented within it; such description should certainly be provisional in the first place. 
The importance of defining technical methods was gtressed by several members, but it was not thought practicable to standardize such methods to any great extent.

It was agreed, however, that a standard set of reference strains should be accumulated which could be used tor comparison of the results obtained in different laboratories. Later, if found technically possible, reference sets of desiccated preparations of the group carbohydrates, and of group antisera might be made available. The Secretary was asked to get in touch with laboratories holding representative collections of strains and to try, first, to get agreement on a suitable standard set of strains.

4. After discussion it was agreed by those present that the pneumococcus was best regarded as a species within the genus Streptococcus.

5. Type identification of pneumococci. Dr. Lund and Dr. Eddy gave brief accounts of theirmethods of classifying the types of pneumococci. Dr. Lund and Dr. Eddy were asked to discuss further among themselves and inform the Secretary of any agreement they could reach.

6. Professor Seelemann opened a discussion on the classification of the so-called greening streptococci. After discussion it was agreed that it would be useful to circulate a number of straing to several laboratories interested in this work, to compare the methods used and the diagnosis arrived at, by different workers. The Secretary was asked to arrange this.

7. The Secretary reported the progress of the Panel set up to define a neotype culture for the species Streptococcus agalactiae. It was agreed that, before the strain V8 was accepted, the Panelshould be asked again whether another strain, e.g. G. 19 was not preferable since V8 commonly fails to ferment salicin.

8. Dr. Pattison introduced his paper on the nomenclature of $S$. agalactiae. In the discussion it was emphasized that, in reports on work done with $S$. agalactiae, it was very important to record the type of the strain used.

9. It was agreed that the type of $S$. pyogenes known as "Red Lake" should be accepted and given the number 49.

10. After discussion it was agreed that the Subcommittee served a useful purpose. The Secretary was asked to find out whether there were other persons interested in its field who might be invited to serve on the Subcommittee. It was 
BACTERIOLOGICAL NOMENCLATURE

Page 121

AND TAXONOMY

felt that any member who had taken no part in the Subcommittee's activities gince 1953 might be asked whether he wished to continue as a member.

Dr. Allison was asked to continue to serve as the Chairman and Dr. Williams as the Secretary of the Subcommittee until the next meeting.

January, 1959

List of Active Members, January, 1959

Dr. V.D. Allison, The Laboratories, Belfast City Hospital, Belfast, Northern Ireland.

Dr. B. Eddy, National Institute of Health, Bethesda 14, Maryland, U.S.A.

Dr. R. M. Fry, Public Health Laboratory, Tennis Court Road, Cambridge.

Professor O. Guthof, Institute of Hygiene, Köln University, Fúrst-Pückler-Strasse 56, Köln-Lindental, Germany.

Professor P. Arne Hansen, Maryland State Board of Agri culture, Live Stock Sanitary Service Laboratory, College Park, Maryland, U.S.A.

Dr. F. Kauffmann, State Serum Institute, Amager Boulevard 80 , Copenhagen, Denmark.

Dr. R. Lancefield, Rockefeller Institute for Medical Research, 66th St. \& York Avenue, New York 21, N. Y., U.S.A.

Dr. E.M. Lund, State Serum Institute, Amager Boulevard 80, Copenhagen, Denmark.

Dr. C. MacLaod, New York University College of Medicine, Department of Microbiology, 477 First Avenue, New York 16, N.Y., U.S.A.

Dr. A. T.R. Mattick, National Institute for Research in Dairying, Shinfield, Reading, Berks.

Dr. G. Mocquot, Station Centrale de Microbiologie et Recherches Laitieres, Jouy-en-Josas, France.

Dr. C.F. Niven, Jr. American Meat Institute Foundation, 939 E. 57 th Street, Chicago, Illinois, U.S.A.

Dr. R. Pakula, Państwowy Zaklad Higieny Centrala, Ul. Chocimska 24, Warsaw, Poland.

Dr. I. H. Pattison, Agricultural Research Council, Field Station, Compton, Newbury, Berks. 
Page 122

IN TER NATIONAL BULLETIN

Professor M. Seelemann, Institute für Milchhygiene, Hermann Weigmannstr. 3/11, Kiel, Germany.

Dr. K. Skadhauge, State Serum Institute, Amager Boulevard 80 , Copenhagen, Denmark.

Dr. A.W. Stableforth, Ministry of Agriculture \& Fisheries, New Haw, Weybridge, Surrey.

Dr. E. Updyke, Streptococcus Laboratory, P.O. Box 185, Chamblee, Georgia, U.S.A.

Dr. R. Wahl, Institut Pasteur, 25 rue du Docteur Roux, Paris XV, France.

Dr. R.E. O. Williams, Streptococcus Reference Laboratory, Colindale Avenue, London N.W. 9. 